\title{
DÜBLIN
}

Technological University Dublin

ARROW@TU Dublin

Articles

School of Food Science and Environmental

Health

2019

\section{Thermostable phytase in feed and fuel industries}

\author{
Ushasree Mrudula Vasudevan \\ CSIR-National Institute for Interdisciplinary Science and Technology, Kerala, India \\ Amit Jaiswal \\ Technological University Dublin, amit.jaiswal@tudublin.ie \\ Shyam Krishna \\ MIMS Research Foundation, Kerala, India
}

See next page for additional authors

Follow this and additional works at: https://arrow.tudublin.ie/schfsehart

Part of the Chemistry Commons, Food Chemistry Commons, Oil, Gas, and Energy Commons, and the Other Food Science Commons

\section{Recommended Citation}

Ushasree Mrudula Vasudevan, Amit K. Jaiswal, Shyam Krishna, Ashok Pandey, Thermostable phytase in feed and fuel industries, Bioresource Technology, Volume 278, 2019, Pages 400-407, ISSN 0960-8524, DOI: 10.1016/j.biortech.2019.01.065.

This Article is brought to you for free and open access by the School of Food Science and Environmental Health at ARROW@TU Dublin. It has been accepted for inclusion in Articles by an authorized administrator of ARROW@TU Dublin. For more information, please contact arrow.admin@tudublin.ie, aisling.coyne@tudublin.ie, gerard.connolly@tudublin.ie.

Funder: Indian Council of Medical Research, New Delhi;

Department of Biotechnology, New Delhi

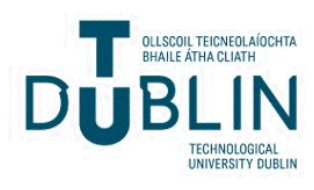


Authors

Ushasree Mrudula Vasudevan, Amit Jaiswal, Shyam Krishna, and Ashok Pandey

This article is available at ARROW@TU Dublin: https://arrow.tudublin.ie/schfsehart/429 
Review

\title{
Thermostable phytase in feed and fuel industries
}

\author{
Ushasree Mrudula Vasudevan $^{\mathrm{a}, *}$, Amit K. Jaiswal ${ }^{\mathrm{b}}$, Shyam Krishna ${ }^{\mathrm{c}}$, Ashok Pandey ${ }^{\mathrm{d}}$ \\ ${ }^{a}$ Biotechnology Division, CSIR-National Institute for Interdisciplinary Science and Technology, Trivandrum 695 019, Kerala, India \\ ${ }^{\mathrm{b}}$ School of Food Science and Environmental Health, College of Sciences and Health, Technological University Dublin, Cathal Brugha Street, Dublin 1, Ireland \\ ${ }^{\mathrm{c}}$ MIMS Research Foundation, Calicut 673 007, Kerala, India \\ ${ }^{\mathrm{d}}$ Centre for Innovation and Translational Research, CSIR-Indian Institute of Toxicology Research, Lucknow 226001 , India
}

\section{A R T I C L E I N F O}

\section{Keywords:}

Phytase

Thermostability

Glycosylation

Ethanol

DDGS

\begin{abstract}
A B S T R A C T
Phytase with wide ranging biochemical properties has long been utilized in a multitude of industries, even so, thermostability plays a crucial factor in choosing the right phytase in a few of the sectors. Mesophilic phytases are not considered to be a viable option in the feed industry owing to its limited stability in the required feed processing temperature. In the recent past, inclusion of thermostable phytase in fuel ethanol production from starch based raw material has been demonstrated with economic benefits. Therefore, considerable emphasis has been placed on using complementary approaches such as mining of extremophilic microbial wealth, encapsulation and using enzyme engineering for obtaining stable phytase variants. This article means to give an insight on role of thermostable phytases in feed and fuel industries and methods for its development, highlighting molecular determinants of thermostability.
\end{abstract}

\section{Introduction}

Feeding swine and poultry is expensive as the feed costs account for about 60-70 percent of the costs of livestock production (Ravindran, 2013a,b; Debbie, 2018). Furthermore, up to one-quarter of the feed get wasted, because the animals lack the enzymes that would allow them to digest it (International poultry production, 2014). Phosphorus (P) is the nutrient with third economic value in monogastric diet formulation after energy and amino acids (Lamid et al, 2018). Phytin accounts for up to $80 \%$ of all the $\mathrm{P}$ in plant seeds and their by-products which are the main ingredients for poultry, swine and ruminants. Phytate accumulated in the seed aleuronic layer and the embryo, chelates magnesium, zinc, calcium and iron. Likewise, it forms complexes with proteins and carbohydrates leading to inhibition of their hydrolysis. Presence of phytate in the feed alters the secretion of endogenous compounds such as animal digestive enzymes, $\mathrm{HCl}$, mucin etc and hence, availability of energy and amino acids are reduced. Phytates are poorly utilized by non-ruminant animals because of the low activity of phytase in their digestive tract. Hence, there is a growing concern over the adverse impact of antinutritional property of phytate on animal performance, phosphorus pollution of effluents from intensive animal operations and the skyrocketing price of inorganic phosphates. As a result, for the last two decades phytate degrading enzyme, phytase from microbial sources has emerged as the primary feed enzyme worldwide. The competence of microbial phytases to release the phytate-bound phosphorous and the potential benefits of this exogenous feed enzyme in improving nutrient digestion and bird performance are well recognized (Selle and Ravindran, 2007).

Phytases have been used commercially in poultry diets for over 20 years and its use will continue to grow (Amerah et al, 2011). According to Global Market Insights, Inc., the animal feed enzymes industry, which accumulated a revenue of USD $\$ 1.1$ billion in 2016, is set to surpass USD $\$ 2$ billion by 2024 (Feed additives, 2017). Among the different products of animal feed enzyme market including phytases, carbohydrases, and proteases, phytase segment constitute the largest market, as of 2015 , with a share of $83.6 \%$ of the total industry in terms of revenue (Grand View Research, 2017). The main market players in phytase production are Novozymes, DuPont (Danisco), AB Enzymes, DSM, BASF, etc. The sales volume of Phytases increased from 114235 MT in 2012 to 152622 MT in 2016, with an average growth rate of 5.96\%. New Global Phytases Market Report (Forecast of Global Phytases Market 2023) covers market forecast projects that Over the next five years, Phytases will register a 7.9\% CAGR in terms of revenue, reach US $\$ 590$ million by 2023, from US\$ 380 million in 2017 (Digital Journal, 2018).

Despite the wealth of knowledge on phytase and their wider acceptance as a feed supplement, achieving consistent results in animal performance is still remaining a major limitation in the feed industry.

\footnotetext{
* Corresponding author.

E-mail address: ushusbt@gmail.com (U. Mrudula Vasudevan).
} 
The huge information available in literature on phytases from microbial sources, their differential performance (Wyss et al., 1999; Mullaney et al., 2000; Vohra and Satyanarayana, 2003; Oh et al., 2004; Kaur et al., 2007; Fu et al., 2008; Ushasree et al., 2016; Priyodip et al., 2017; Cangussu et al., 2018) and efficacy of different commercial products demonstrate how biochemical characteristics of particular phytase limit its use in industry (Wu et al., 2015; Jones et al., 2010; MenezesBlackburn et al., 2015; Shanmugam, 2018). Being proteins, highly complex three-dimensional molecular structure of phytases has important implication in their stability during high-temperature feed manufacture. This provided the researchers in manifold discipline to act together with a potential prospect to enhance the phytase performance through immobilization (Davis, 2003; Menezes-Blackburn et al., 2011; Shankar et al., 2015) or encapsulation (Rathnayake et al., 2018; Isakova et al., 2018), enzyme mining from extremophiles (Berka et al., 1998; Sarmiento et al., 2015; Dokuzparmak et al., 2017), mimicking enzyme evolution in the laboratory (Hibbert and Dalby, 2005; Kim and Lei, 2008) and using rational, computer-assisted enzyme engineering strategies (Zhang et al., 2007; Wang et al., 2018; Rigoldi et al., 2018).

Aside from animal feed industry, in the past decade, thermostable phytases have attained great consideration in biofuel industry. Inclusion of this enzyme in bioethanol production from starch based feed stock is reported to be beneficial as it solves waste disposal problem, simultaneously creates a higher value added ethanol co-product, and improves the overall efficiency of ethanol production (Shetty et al., 2008). The objective of this review is to draw attention of the global phytase research communities to the growing demand of thermosatble phytases in feed sector. This review discusses recent advances and effective strategies in the development of thermostable phytases, highlighting molecular determinants of thermostability. In addition, this review brings in to focus the benefits associated with the application of thermostable phytases in ethanol production. The review concludes by suggesting the direction of future research in development of thermostable phytases.

\section{Temperature as a decisive factor to decide the right phytase in feed}

Animal feeds may become contaminated with harmful bacteria. Salmonella spp. is the major microbiological hazard in animal feed which can cause animal contamination (Jones, 2011). For this reason, most of the countries prescribed requisite programs for the control of Salmonella using heat treatments (Jones and Richardson, 2004). Feeds are often pelleted for improving the digestibility, especially the starch fraction of the feed and reduction in microbial contamination (Cox et al., 1986; Lewis, 2011). Further-more, pelleting of feed reduces the troubles with dust, makes the feed easier to consume for the livestocks, and it permit incorporation of small amounts of ingredients in the feed and to "lock" the feed mixture (Abdollahi et al., 2013). This pelleting procedure involved adding steam to the feed where temperature can frequently reach up to $90^{\circ} \mathrm{C}$. Most of the microbial phytases are thermostable up to around $70^{\circ} \mathrm{C}$, and feed manufacturing thermal processes beyond this value, dramatically reduces phytase activity (Patridge, 2007). The intrinsic phytase in small grains is inactivated by steam pelleting at temperatures above $80^{\circ} \mathrm{C}$ (Jongbloed and Kemme, 1990). Loss of phytase activity obviously decreases the value of the enzyme and compromise monogastric health as the diets become deficient in available phosphorus (Loop et al., 2012). Extent of these losses which appear to be affected by the type of enzyme preparation as well as by the methods of assessing pelleting temperature and enzyme recovery (Amerah et al., 2011).

Many studies have been conducted to evaluate the difference in thermostability of phytase after pelleting. Previously, the thermostability of two phytase products, Ronozyme NP and Phyzyme XP TP were investigated, and the results demonstrated that more than $80 \%$ of the enzyme activity was preserved following conditioning and pelleting up to $95^{\circ} \mathrm{C}$. Since, pelleting processes at a feed mill normally do not exceed $95^{\circ} \mathrm{C}$; the study concluded that the pelleting will not cause problems to the activity of the studied enzymes (Dorthe, 2010). In a recent study, four commercial phytase products [Quantum Blue G (AB Vista); Ronozyme Hi Phos GT (DSM Nutritional Products); Axtra Phy TPT (Dupont); and Microtech 5000 Plus (Guangdong Vtr Bio-Tech Co., Ltd)] were exposed to four temperatures $\left(65,75,85\right.$, and $\left.95^{\circ} \mathrm{C}\right)$. Residual phytase activity decreased as the temperature increased from 65 to $95{ }^{\circ} \mathrm{C}$ at a rate of $-1.9 \%$ for each $1{ }^{\circ} \mathrm{C}$ raise in conditioning temperature regardless of the product. At $95^{\circ} \mathrm{C}$, Axtra Phy TPT had greater $(\mathrm{P}<0.05)$ residual phytase activity compared with Microtech 5000 Plus, with Quantum Blue G and Ronozyme Hi Phos intermediate. (De Jong et al., 2017).

\subsection{Post pellet phytase application}

Liquid phytase formulation can be applied to feed before pelleting inorder to minimize the activity loss arising from instability of heat sensitive phytases. Though this approach ensures that the enzyme is not exposed to higher temperature, incorporation of liquid enzymes homogenously after pelleting is time consuming and costly as it requires sophisticated spraying instruments designed for individual feed mills. The type of pellet produced, and the percentage of fines affects the homogenous distribution of the additive (Patridge, 2007). In addition, liquid enzymes are inherently less stable in storage than their dry granular counterparts. To avoid complications associated with liquid enzymes, dry thermostable enzyme is a key requirement to the feed industry which allow direct addition of enzyme to the mixer ensuring survival of pelleting step. Comparison of post pellet liquid and dry phytase application to broiler diet has already been demonstrated (Edens et al., 2002). Previously, improvement in phytase thermostability was demonstrated by mixing phytase solution, soluble starch, and sorghum liquor wastes at the ratio of 1:1:10 (v/w/w). The residual phytase activity after $30 \mathrm{~min}$ of treatment at 70 and $80^{\circ} \mathrm{C}$ were about 90 and $18 \%$ of that at $37^{\circ} \mathrm{C}$ respectively (Chang-Chih et al., 2001). Liquid phytase formulations stabilized by means of the addition of polyols, polymers, ethylene glyol and ions exhibiting increased resistance to heat inactivation during prolonged periods of storage have been reported (Barendse et al., 2009; Rodríguez-Fernández et al., 2013).

\subsection{Phytase with inherent stability}

Identifying intrinsically thermostable enzymes is the most active approach currently being investigated to produce enzymes with characteristics suitable for the feed manufacturing industry. Systemic efforts are being done in prospecting new thermostable phytases from thermophilic or mesophilic microbes by conventional screening or by applying advanced molecular techniques (Ushasree et al., 2017). High yielding strains are necessary for enzyme production in industrial processes. Large scale enzyme production from thermophiles faces several challenges such as knowledge on physiology and genetics of such organisms is poor, compared to their mesophilic counterparts; the biomass achieved by these organisms is usually disappointingly low; they are fastidious; and are not recognized as safe (Illanes, 1999). Recombinant expression is a practical method to increase the yield of a target gene. Development of vectors for expression of proteins in various thermophilic hosts have been reported (Drejer et al., 2018). However, use of the novel thermophilic expression systems is still at research level and more work remains before exploitation at industrial scale can be considered (Turner et al., 2007; Drejer et al., 2018). Hence, cloning and expression of thermophilic genes into a suitable and faster growing mesophilic host is regarded as a suitable option for producing thermostable enzyme required for varied purposes (Adams and Kelly, 1998). Table 1 represent an account on thermostable phytases and structural features contributing to thermostability reported during the last decade and their properties. 


\subsection{Coating and immobilization of phytases}

Coating technologies are the most widely used enzyme protection technology used today for the commercial phytases, which will protect the enzyme from pelleting process. However, in many cases, it was observed that, it reduces the enzyme release in the gastrointestinal tract of the animal. Danisco Animal Nutrition in 2009 had launched a new highly-thermostable phytase (Phyzyme XP TPT), which is claimed to be the most thermostable phytase on the market. The Thermo Protection Technology (TPT) developed by Danisco ensures higher efficacy of phytase after exposure to feed conditioning and pelleting temperatures of up to $95^{\circ} \mathrm{C}$, while rapidly releasing the enzyme activity in the animal's gut, without compromising animal performance. The efficacy of this technology was confirmed by independent pelleting trials conducted at Technological Institute, Kolding in Denmark. Spurt in the number of patents issued during the last 10 years also suggest that coating of animal feed enzymes offers greater stability to heat and other physicochemical conditions during processing and storage of feeds. Recently rice bran was used to synthesize dietary fibers in nanoscale using electrospinning technique. Phytase incorporated into these nanofibres demonstrated improved thermal properties in which the enzyme denaturation temperature had increased from 80 to $170{ }^{\circ} \mathrm{C}$. These findings opened up new pathways for stabilization of bio-molecules in nanofibers based on agriculture waste materials (Rathnayake et al., 2018). A new recombinant strain of Yarrowia lipolytica synthesizing encapsulated highly thermostable phytase of Obesumbacterium proteus, which is recommended for use as a premix component of feed compositions in animal husbandry was, described (Isakova et al., 2018). On the other hand, researchers at the Laval University in Quebec (Canada) studied the encapsulation of microbial phytase and its effects on phosphorus bioavailability in rainbow trout (Oncorhynchus mykiss), which concluded that, encapsulation diminished enzyme's ability to liberate phosphorous (Vandenberg et al., 2011).

Effect of immobilization of phytases on thermostability characteristic was also demonstrated by previous studies. Immobilization of two commercial microbial phytases from Aspergillus niger and Escherichia coli on iron-coated allophane increased their thermal stability and improved resistance to proteolysis (Menezes-Blackburn et al., 2011). Zwitterionic amino acid tyrosine was used as a reducing and capping agent to synthesize gold nanoparticles which permitted efficient immobilization of phytase enzyme through charge-switchable electrostatic interactions. The immobilized enzymes exhibited greater thermostability and activity which was proved by detailed kinetic and thermodynamic studies (Shankar et al., 2015). Covalent immobililization of phytase on to multi-walled carbon nanotubes (F-MWNT) was described in which immobilized phytase exhibited improved stability towards temperature than the free phytase. The free phytase retained $27 \%$ and $3 \%$ of relative activity at 80 and $90{ }^{\circ} \mathrm{C}$, respectively after $2 \mathrm{~min}$ of incubations. While immobilized phytase retained about 33 and $51 \%$ activity at the same conditions (Naghshbandi et al., 2018).

\subsection{Thermostability engineering in phytases}

Phytases derived from mesophiles are more extensively explored as phytases produced by thermophiles exhibit low activity at the physiological temperature of animals (Vieille and Zeikus, 1996). Mesophiles adapt their proteins to function optimally at normal environmental conditions and maintain their structural integrity at only a limited range of temperatures. During the past two decades, varieties of attempts including crystallization of phytases from different microbial sources, comparison of mesophilic and thermophilic enzyme variants and random or rational amino acid alterations have shed light on the structural features of phytases contributing structural tolerance at elevated temperature (Shivange and Schwaneberg, 2017; Rebello et al., 2017). 


\subsubsection{Disulfide bridges}

Disulfide bonds in enzymes have high relevance in their biotechnological applications (Bardwell, 2007). Replacement of specific cysteine residues can alter enzyme structure that is inconsistent with catalytic activity by strongly affecting the rate of irreversible enzyme inactivation (Dombkowski et al., 2014). A considerable body of literature suggests that, when disulfide bonds are introduced in phytases, it effectively improved the thermostability characteristics. In early experiments, presence of five disulfide bonds in Aspergillus ficuum phytase was predicted by unfolding studies, by means of guanidinium hydrochloride $(\mathrm{Gu} \cdot \mathrm{HCl})$ as denaturant. Later, the role of these bonds in the conformational stability and catalytic activity was investigated (Ullah and Mullaney, 1996; Wang et al., 2004; Song et al., 2005). Mullaney et al. (2010) reported the relative significance of each of these five bonds using site-directed mutagenesis. This study revealed that removal of Disulfide Bridge 2 resulted in complete loss of activity and other disulfide mutants displayed a broad array of altered catalytic properties including a lower optimum temperature from 58 to $53^{\circ} \mathrm{C}$. In another attempt, four mutants of $A$. niger NRRL 3135 phytase was generated using site-directed mutagenesis of the cysteines that are involved in the formation of a single disulfide bridge. When mutants and the native PhyA were heated to $70^{\circ} \mathrm{C}$ for five minutes, wild type phytase retained $21.3 \%$, while all the DB mutants retained a higher percentage of activity than the wild type. Mutants C31G, C40G, 31G/C40G and C31G/ C40S retained 24.8, 39.3, 49.6 and $84.2 \%$, respectively (Mullaney et al., 2012). In a different study, the disulfide intact monomer and a monomer with broken disulfide bonds of phytase B from Aspergillus niger, were simulated. This study indicated that the disulfide bonds stabilize the $\beta$-sheet containing active site residue Arg66 and destabilize the $\alpha$-helix that contains the catalytic residue Asp319 which is essential for maintaining the native conformation of the catalytic site (Kumar et al., 2013).

At the same time, beta-propeller phytases (BPPs) from Gram-positive bacteria do not carry disulfide bonds and introduction of new disulfide bonds did not alter its enzymatic properties (Cheng et al., 2007). Thermostability of an acid stable phytase from Acidobacteria was improved by introducing four additional disulfide bridges by redesigning a mutant using Design 2.0. The amino acid residues selected for constructing the four extra disulfide bridges were Thr101-Ser307, Thr354-Val381, Val352-Phe398, and Ala229-Met364. Two of the engineered phytases showed a half-life time at $60^{\circ} \mathrm{C}$ and $80^{\circ} \mathrm{C}$, respectively which is $3.0 \times$ and $2.8 \times$ longer than the wild. This study proved Design 2.0 to be an efficient tool for the rational design of enzymes by manipulating disulfide bridges and showed that addition of disulfide bridges was effective in enhancing the thermal resistance of an enzyme while retaining its activity level as well as acidophilic and acidostable properties (Tan et al., 2016a,b). Recently, an in silico analysis on structural relationships between disulfide-bearing phytases and disulfide-free phytases was conducted. Six out of 9 phytases used in the study carried three or more disulfide bonds while the others lack any disulfide bonds. Results demonstrated a remarkable correlation between the presence of disulfide bond and the number of amino acid in each phytase. Additionally, phytases containing disulfide bonds have some identical characteristic including aliphatic index (AI), isoelectric $\mathrm{pH}$ (PI), amino acids percentage, molecular weights (MW) and 3D structure rather than disulfide-free phytases do. Evolutionary analysis showed that phytases with disulfide bond exhibited the same evolutionary course (Ghasemian et al., 2017).

\subsubsection{Alteration in hydrogen bond network}

Functional importance of hydrogen bonds and ionic interactions in supporting the thermostability in phytases has already been demonstrated. In comparison with the commercial phyA derived from A. niger, Aspergillus fumigatus phytase is well-known for its heat resilience as it retains $90 \%$ of its initial activity after being heated at $100{ }^{\circ} \mathrm{C}$ for $20 \mathrm{~min}$. These two enzymes possess very similar crystal structures however, sharing only $66 \%$ sequence homology. This thermostability in A. fumigatus phytase was analyzed to be associated with hydrogen bonding network in E35 to S42 region and ionic interactions between R168 and D161 and between R248 and D244 which was proved by single or combined loss of function mutations (E35A, R168A, and R248A). And when corresponding substitutions were introduced in $A$. niger phytase, the developed quadruple mutant (A58E P65S Q191R T271R) retained $20 \%$ greater activity than that of the wild after being heated at $80^{\circ} \mathrm{C}$ for $10 \mathrm{~min}$ (Zhang et al., 2007). Introduction of side-chain hydrogen bond to stabilize a loop structure (Gln137-Asn144) was reported in E. coli appA (pH 2.5 acid phosphatase) in mutant D144N which showed 15\% enhancement in thermostability and $4-5{ }^{\circ} \mathrm{C}$ increases in the melting temperatures (Kim et al., 2008). Two phytase variants K46E and K65E/ K97M/S209G developed by directed evolution in appA also increased hydrogen bonding and subsequently exhibited over $20 \%$ improvement in thermostability $\left(80^{\circ} \mathrm{C}\right.$ for $10 \mathrm{~min}$ ), and $6-7^{\circ} \mathrm{C}$ increases in melting temperatures (Kim and Lei, 2008). In another study, $\mathrm{Mn}^{2}+$-dITP $\left(2^{\prime}-\right.$ deoxyinosine $5^{\prime}$-triphosphate) random mutation method in a proteaseresistance phytase gene of Penicillium sp., developed two mutants (T11A/G56E/L65F, Q144H/L151S and T11A/H37Y/G56E/L65F/ Q144H/L151S/N354D) with improved thermal stability and optimal temperature. Both the mutants retained about $72.81 \%$ and $92.43 \%$ of the initial activity, respectively after a heat treatment at $100{ }^{\circ} \mathrm{C}$ for $5 \mathrm{~min}$ and this stability was attributed to the formation of new hydrogen bonds among the adjacent secondary structures (Zhao et al., 2010). Formerly, using molecular dynamics simulation, Aspergillus niger PhyA and its thermostable mutant with $20 \%$ greater thermostability was compared by evaluating atomic root mean square deviation, radius of gyration, and number of hydrogen bonds and salt bridges. The results concluded that loops are the major secondary structural elements contributing to stability, and in addition, the location of hydrogen bonds rather than the number play the crucial role in thermostability (Noorbatcha et al., 2013).

Improved hydrogen bonding network in Yersinia mollaretii phytase by combining key beneficial substitutions identified through directed evolution resulted in reduced flexibility at loops and subsequent improvement in thermal resistance (melting temperature increased by $3{ }^{\circ} \mathrm{C}$ than the wild and the residual activity improved from 35 to $89 \%$ at $58{ }^{\circ} \mathrm{C}$ and 20 min incubation) (Shivange et al., 2016). Recently, a rational protein design approach was used to mutate six putative solventaccessible amino acid residues (K74, K75, K180, R181, K183, and $\mathrm{K} 363$ ) in E. coli phytase to introduce hydrogen bonds (K74D/K75Q/ K180N/R181N/K183S/K363N). The melting temperature (Tm) of wild and mutant phytases was determined using Circular Dichroism (CD) spectroscopy. As the temperature gradually increased from 25 to $85^{\circ} \mathrm{C}$, the $\mathrm{CD}$ spectrum of all the phytases revealed a drop in $\alpha$-helix content. The Tm value obtained for wild phytase was $60.3^{\circ} \mathrm{C}$. While the mutants showed a shift in melting temperature of $1.2-3.8^{\circ} \mathrm{C}$ suggesting the stabilizing role of substitutions in protecting the phytase during the thermal denaturation process (Wang et al., 2018).

\subsubsection{Glyco engineering phytase}

Protein glycosylation is one of the most common structural modifications employed by biological systems to expand proteome diversity. Protein residues have been found to be glycosylated with a variety of glycans at asparagine residues (N-linked glycosylation through Asn-X-Thr/Ser recognition sequence) and at serine or threonine residues (O-linked glycosylation). It is well known that the glycans have an important role in augmenting the overall stability of glycoproteins and rational manipulation of the glycosylation parameters through introduction of new glycosylation sites in proteins provide ample opportunities to optimize the operational stability of both industrial and pharmaceutical proteins. The increase in glycosylation degree rigidifies the protein structure and increases the effective distance between the protein electrostatics (Solá and Griebenow, 2009). Glycosylation in Aspergillus niger and Aspergillus japonicus phytase was 
reported for its functional expression and thermostability when expressed from yeast systems (Han and Lei, 1999; Fonseca-Maldonado et al., 2014). Formerly, a number of studies have been conducted to engineer the glycosylation in these enzymes. Addition of $\mathrm{N}$-glycosylation sites in E. coli appA phytase showed glycosylation level 48, 89 and $145 \%$ for the mutants A131N/ V134N/D207N/S211N, C200N/D207N/ S211N, and A131N/ V134N/C200N/D207N/S211N respectively (Rodriguez et al., 2000). In a different study, substitutions of glycosylation sites in a codon optimized E. coli, the mutant (Q258N/Q349N) showed a $40 \%$ enhancement in thermostability $\left(85^{\circ} \mathrm{C}\right.$ for $10 \mathrm{~min}$ ) and $4-5{ }^{\circ} \mathrm{C}$ increases in the melting temperatures $(\mathrm{Tm})$ than the wild (Yao et al., 2013). Wu et al. (2014), carried out a rational design experiment in which $N$-glycosylation motif from Citrobacter phytases was introduced in $E$. coli phytase. The outcome of the study was promising as three of the single mutants retained 5.6-9.5\% activity after treatment at $80^{\circ} \mathrm{C}$. In addition, the mutant carrying triple glycosylation motifs exhibited $27 \%$ residual activity ( $1.8 \%$ for wild type).

\subsubsection{Other structural elements contributing stability}

Based on sequence alignment and molecular modeling of $E$. coli phytase, a divergent residue, Ser51 in close proximity to the catalytic site was mutated to A, T, D, K and I by site-directed mutagenesis. Here the electrostatic interaction and side chain structure near the active site in the mutants contributed to greater activity over $\mathrm{pH} 2.0-5.5$, and increased thermal stability (Fu et al., 2009). Fei et al. (2013a) reported that the C-terminal end of $E$. coli phytase plays an important role in thermostability. When heated at $80{ }^{\circ} \mathrm{C}$ for $10 \mathrm{~min}$, the C-lose mutants Q307D, Y311K, and I427L constructed in their study exhibited $39.07 \%$ thermostability enhancement than the wild-type. In another attempt of multiple-factors rational design-new mutation strategy by combining alteration in protein flexibility, protein surface, and salt bridges in $E$. coli appA, the authors reported that single and multiple mutants developed by this strategy improved thermostability (Fei et al., 2013b).

A further study report development of an improved variant of Yersinia mollaretii phytase using newly developed OmniChange method for multi-site saturation mutagenesis with $32 \%$ improved residual activity $\left(58^{\circ} \mathrm{C}\right.$ for $\left.20 \mathrm{~min}\right), 2{ }^{\circ} \mathrm{C}$ increased apparent melting temperature (Tm) when compared to the wild-type Ymphytase. Here the mutant developed with residue change V298Fcontributed to improved thermal resistance by introducing aromatic-aromatic interactions (Shivange et al., 2014). In addition to hydrogen bonds and disulfide bridges, introduction of other structural factors such as increasing $\alpha$-helix content and greater exposed hydrophobic surface in E. coli appA enhanced the thermal tolerance exhibiting $7.5^{\circ} \mathrm{C}$ increase in the melting temperatures $\left(\mathrm{T}_{\mathrm{m}}\right)$ (Wang et al., 2015). Among the six mutants generated by using site-directed mutagenesis in E. coli appA, two mutants W46E and $\mathrm{K} 24 \mathrm{E}$ showed strong thermostability and retained more than $60 \%$ activity after heat treatment for $20 \mathrm{~min}$ at $90^{\circ} \mathrm{C}$. Here the change in residual charge of the protein was suggested as the reason for enhancement of thermostability (Zhang et al., 2016). Recently, phytases from Yersinia enterocolitica and $Y$. kristensenii were mutated by optimizing amino acid polarity and charge. In this study, the variants developed (F89S, E226H, and F89S/E226H) at the predicted pepsin/trypsin cleavage sites, elevated pepsin resistance and thermostability (Niu et al., 2017).

\section{Phytase: application in ethanol production from starch-based feedstocks}

To trim down the dependence on fossil fuels and greenhouse gas emissions, in many countries, the governments direct to use alternate biofuels. With high agricultural productivity and advances in infrastructure, currently, ethanol is the most widely used biofuel in the world. Moreover, over 64 countries now have active programmes promoting the use of ethanol as a mainstream fuel. The International Energy Agency predicts that, together, conventional and advanced biofuels will represent $8 \%$ of the transport energy consumption by 2025. In spite of a major research swing over to the second, third and fourth generation of biofuels, fuel grade ethanol from starch-based feedstock still continues to grow on a global basis. In this scenario, beyond basic needs for better and lower cost starch hydrolyzing enzymes, the ethanol industry is constantly searching for novel enzymes that improve the production efficiency, provide energy saving and create value added co-products in the conversion of food crops to fuel.

\subsection{Requirement of thermostable phytase in ethanol production}

Phytic acid present in cereal based raw materials can complex with many compounds (polyvalent cations such as Fe, $\mathrm{Zn}, \mathrm{Ca}$ and $\mathrm{Mg}$; proteins and starch) and therefore limit their availability to the yeast during the alcoholic fermentation process (Mikulski et al., 2015). Phytates bind to polysaccharides and lower the susceptibility to enzymatic hydrolysis thereby lowering the amount of fermentable sugars. Binding with starch occurs either directly by means of hydrogen bonds or indirectly via starch-associated proteins. Hydrolysis of phytic acid using phytase is the one possible route to tackle this issue. Release of inositol from phytic acid would improve yeast ethanol tolerance ability resulting in higher ethanol yields (Chi et al., 1999; Keiji et al., 2004). In addition, it allow more minerals eg $\mathrm{Ca}^{2+}$ to be available to the fermenting yeast; remove the phytic acid interference with mineral such as $\mathrm{Ca}^{2+}, \mathrm{Mg}^{2+}, \mathrm{Zn}^{2+}$ and $\mathrm{Fe}^{2+}$ that reduces the stability of different types of amylases especially those from Bacillus and A. niger used in ethanol production; availability of more free phosphorous, minerals and vitamins to the fermenting yeast improves which subsequently increase the ethanol yield (Fig. 1) (Veit et al., 2001).

Within the same plant species, different genetic lines show difference in phytic acid content (Raboy et al., 2001). Hence, studies on the analysis of phytic acid concentration in different raw plant materials have been conducted to determine the limitations caused by decreased availability of biogenic compounds bound to phytase (Frontela et al., 2008; Tahir et al., 2012). Mikulski and Kłosowski. (2015) have evaluated the concentration of phytic acid in selected raw starchy materials (maize, rye, wheat and triticale grain) used for ethanol production and the rate of phytate hydrolysis using various microbial phytases for the further development of more efficient and cost-effective industrial fermentation procedures.

In ethanol production process from starch based raw materials, milled grain is slurried with water and a thermostable alpha amylase enzyme. The slurry is cooked to $105-150^{\circ} \mathrm{C}$ to gelatinize and liquefy the starch in the liquefaction process. The resulting mash is cooled and a secondary enzyme, glucoamylase, is added to convert the liquefied starch to fermentable sugars in the saccharification stage. In a further step, addition of yeast allows fermentation of the sugars to ethanol and carbon dioxide. In addition to alpha amylase and glucoamylase, protease can be added to improve the fermentation process, and phytase, can be added either in the liquefaction stage to enhance the performance of thermostable alpha amylase, or in the yeast fermentation process. The temperature range in liquefaction process is $76-87^{\circ} \mathrm{C}$ for 90-140 min and hence, application of thermostable phytases are preferred at this stage as they can perform efficient hydrolysis (Don Cannon, 2014, DuPont Danisco Animal Nutrition). Earlier, phytases applied in addition to alpha-amylase during liquefaction have been reported to reduce slurry viscosities and stabilization of alpha-amylase (SPEZYMETM Xtra). Improved alpha-amylase activity resulted in better starch hydrolysis (Shetty et al., 2008). Effect of phytase addition on ethanol yield was investigated for E-Mill dry grind corn process and it was reported that the final ethanol concentrations were higher in E-Mill processing with phytase addition $(17.4 \% \mathrm{v} / \mathrm{v})$ than without addition of phytase (16.6\% v/v) (Khullar et al., 2011). Recently, a patent on methods for application of thermostable phytase for ethanol production was reported (Tan et al., 2018). A thermo-acid stable phytase from 

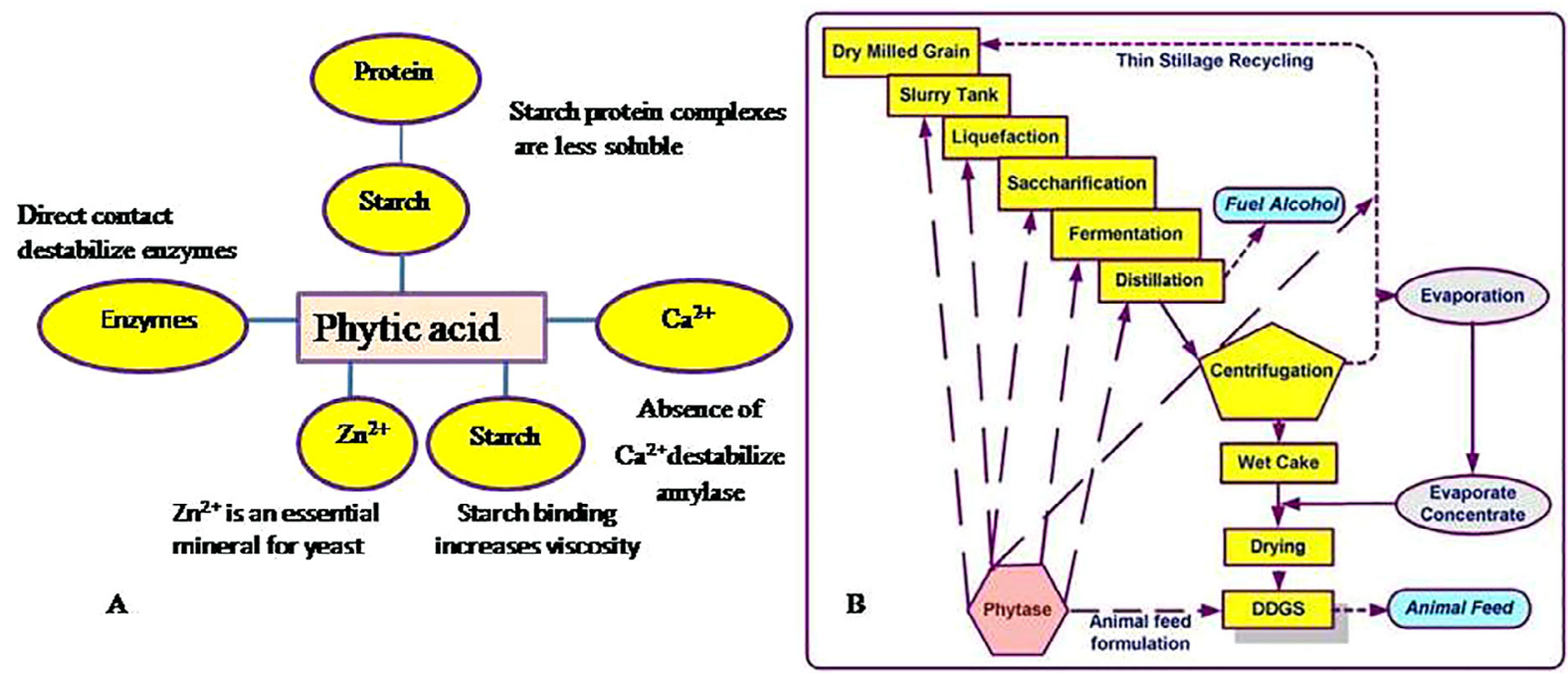

Fig. 1. (A) Phytate and its interference in ethanol production; (B) application of phytase in different steps in ethanol production from starch based plant material (Shetty et al., 2008; Fuel ethanol workshop presentation given by Dr. Jay Shetty; Don Cannon, 2014, Dupont Danisco Animal Nutrition).

thermophilic mould Thermomyces lanuginosus SSBP was used to enhance bioethanol production from Colocasia esculenta was demonstrated in which the enzyme reduced phytate content in Colocasia esculenta starch (from $1.43 \mathrm{mg} / \mathrm{g}$ to $0.05 \mathrm{mg} / \mathrm{g}$ ) that resulted in an improvement in the availability of fermentable sugars with a concomitant reduction in viscosity and 1.59-fold improvement in ethanol production (Makolomakwa et al., 2017). Thermostable recombinant Buttiauxiella phytase was included in the starch processing step in ethanol production to reduce the levels of phytic acid in end-product (Kensch et al., 2016; Breneman et al., 2013).

\subsection{Phytase for high value ethanol co-product: low phytate DDGS}

When dry-grind process is used for the production of ethanol from cereal grains during which the starch is saccharified and fermented by yeast to produce ethanol. The remaining nonfermentable components are recovered as distillers dried grains with solubles (DDGS) for feeding the livestocks. Due to the nutritional value present in DDGS, it quickly gained attention from the markets and in 2015 achieved a significant share, about $23 \%$, of the non-ruminant animal feeding markets, such as poultry and swine industries. In the dry grind process, phytate present in the grain is concentrated about threefold in DDGS which cannot be digested by monogastric animals, such as poultry and swines, which in turn produce manure with high levels of phosphorus. Low phytate DDGS can have significantly higher true metabolizable energy (TME) and digestibility of some amino acids, especially those present at high concentrations in endogenous protein.

In order to increase the nutritional value of DDGS different strategies are adopted such as by extracting phytate from DDGS or inclusion of phytase in ethanol production. Phytate is a highly-valued chemical used as food additive, preservative and antioxidant. In recent years, the beneficial effects of phytates have been highlighted and explored by the pharmaceutical industry, particularly in the prevention of renal calculi, diabetes, some types of cancer and Parkinson's disease. Recently, diverse efforts have been taken to recover phytate from DDGS in the downstream processing of dry-grind co-products as it can profit by more revenue to ethanol industry and feed industry by improving feed digestability. He et al. (2017) have used AG 1-X8 anion exchange resin to remove and purify phytates from thin stillage, and near $100 \%$ efficiency of adsorption and over $90 \%$ desorption from the resin beads was achieved. Several attempts have also been taken to increase the degradation of phytate throughout or after the fermentation using phytase. Noureddini and Dang (2009) have used phytase from A. niger to catalyze phytate hydrolysis in Whole Stillage. Whereas Khullar et al. (2011) proposed a step of incubation with phytase prior to corn saccharification. In this, addition of phytases in the E-Mill process was described and it resulted in DDGS with lower residual starch content (6.6\%) compared to E-Mill process without phytase incubation $(8.1 \%)$. DDGS produced from E-Mill processing with phytase incubation also had higher protein content $(36.5 \%)$ compared to control processing (34.2\%). In another study, Liu (2014), described addition of industrial phytase preparations (Natuphos and Ronozyme) to treat commercially made thin stillage (TS) and a complete phytate hydrolysis was achieved within 5-60 min of enzymatic treatment. In another study, incorporation of phytase along with non-starch hydrolase and protease promoted fermentation performance in corn dry-grind process for ethanol and it produced DDGS with lower amounts of nondigestible carbohydrates. Ethanol production rate increased to $1.16 \mathrm{~g} / \mathrm{g}$ dry corn per hour, and thin stillage wet solids increased by $2 \% \mathrm{w} / \mathrm{w}$ (Luangthongkam et al., 2015). Phytase displayed on the $S$. cerevisiae surface by fusing the enzyme with the glycosylphosphatidylinositol (GPI)-anchoring system was used as a promising technology to increase the efficiency of ethanol production and decrease the phytate phosphate content in DDGS (Chen, 2017).

\section{Conclusions}

Numerous thermostable phytases have been reported from thermophiles. This intrinsic thermostability can be combined with high activity at physiological temperatures using directed evolution strategies with little trade-off in activity. Further, advances in current computational enzyme design approaches have not yet been wholly exploited in phytase research. Hence, by initiating research on broadening the activity profile in hyperthermophilic phytases and extending the phytase engineering research in to more communities globally, it is expected that in near future the phytase with ideal stability parameters will be developed.

\section{Acknowledgements}

One of the authors (MVU) thanks the Indian Council of Medical Research, New Delhi and Department of Biotechnology, New Delhi (Grant No. GAP 1410) for the financial support. 


\section{References}

Abdollahi, M.R., Ravindran, V., Svihus, B., 2013. Pelleting of broiler diets: an overview with emphasis on pellet quality and nutritional value. Anim. Feed Sci. Technol. 179 (s1-4), 1-23.

Adams, M.W., Kelly, R.M., 1998. Finding and using hyperthermophilic enzymes. Trends Biotechnol. 16, 329-332.

All about feed, 2017. Feed Additives. Feed Enzyme Market to Exceed US\$2b by 2024 https://www.allaboutfeed.net/Feed-Additives/Articles/2017/8/Feed-enzymemarket-to-exceed-US2b-by-2024-170343E/.

Amerah, A.M., Gilbert, C., Simmins, P.H., Ravindran, V., 2011. Influence of feed processing on the efficacy of exogenous enzymes in broiler diets. World's Poult. Sci. J. 67. https://doi.org/10.1017/S0043933911000031.

Bardwell, J.C.A., 2007. 5 - Disulfide bond formation enzymes. The Enzymes 25, 111-128. https://doi.org/10.1016/S1874-6047(07)25005-X.

Barendse, R.C.M., Meesters, G.M.H., Harz, H.P., 2009. Preparation of Phytase-containing Granulates for Use in Animal Feed (US7611701B2).

Berka, R.M., Rey, M.W., Brown, K.M., Byun, T., Klotz, A.V., 1998. Molecular characterization and expression of a phytase gene from the thermophilic fungus Thermomyces lanuginosus. Appl. Environ. Microbiol. 64 (11), 4423-4427.

Boukhris, I., Farhat-Khemakhem, A., Blibech, M., Bouchaala, K., Chouayekh, H., 2015. Characterization of an extremely salt-tolerant and thermostable phytase from Bacillus amyloliquefaciens US573. Int. J. Biol. Macromol. 80, 581-587. https://doi.org/10. 1016/j.ijbiomac.2015.07.014.

Breneman, S., Lantero, O., Bradley Paulson, B., Shetty, J., 2013. Glucoamylase and Buttiauxella Phytase During Saccharification. CA2718017C. Danisco US Inc.

Bujna, E., Rezessy-Szabó, J.M., Nguyen, D.V., Nguyen, D.Q., 2016. Production and some properties of extracellular phytase from Thermomyces lanuginosus IMI 096218 on rice flour as substrate. Mycosphere 7 (10), 1576-1587.

Cangussu, A.S.R., Aires, A.D., Aguiar, R.W.S., Bordignon-Junior, S.E., Viana, K.F., Barbosa, L.C.B., Cangussu, E.W.D.S., Brandi, I.V., Portella, A.C.F., Dos Santos, G.R., Sobrinho, E.M., Lima, W.J.N., 2018. Characterization of the catalytic structure of plant phytase, protein tyrosine phosphatase-like phytase, and histidine acid phytases and their biotechnological applications. Enzyme Res. 2018. https://doi.org/10.1155/ 2018/8240698. eCollection.

Chang-Chih, C., Ching-Tsan, H., Kou-Joan, C., 2001. Improvement of phytase thermostability by using sorghum liquor wastes supplemented with starch. Biotechnol. Lett. 23, 331-333.

Chen, X., 2017. Yeast cell surface display: an efficient strategy for improvement of bioethanol fermentation performance. Bioengineered 8 (2), 115-119.

Cheng, C., Wong, K.B., Lim, B.L., 2007. The effect of disulfide bond on the conformational stability and catalytic activity of beta-propeller phytase. Protein Pept. Lett 14 (2), 175-183.

Chi, Z., Kohlwein, S.D., Paltauf, F., 1999. Role of phosphatidylinositol (PI) in ethanol production and ethanol tolerance by a high ethanol producing yeast. J. Ind. Microbiol. Biotechnol. 22, 58-63.

Cox, N.A., Burdick, D., Bailey, J.S., Thomson, J.E., 1986. Effect of the steam conditioning and pelleting process on the microbiology and quality of commercial-type poultry feeds. Poult. Sci. 65 (4), 704-709.

Davis, B.G., 2003. Chemical modification of biocatalysts. Curr. Opin. Biotechnol. 14 (4), 379-386.

Debbie, J., 2018. 4-Step Guide to Pig Feeding and Rations. Farmers Weekly. https:// www.fwi.co.uk/livestock/4-step-guide-pig-feeding-rations.

De Jong, J.A., Woodworth, J.C., DeRouchey, J.M., Goodband, R.D., Tokach, M.D., Dritz, S.S., Stark, C.R., Jones, C.K., 2017. Stability of four commercial phytase products under increasing thermal conditioning temperatures. Transl. Anim. Sci. 1 (3), 255-260. https://doi.org/10.2527/tas2017.0030.

Digital Journal, 2018. Global Phytases Market Will Grow at a CAGR 7.9\% and Reach USD 590 Million by 2023, from USD 380 Million in 2017. http://www.digitaljournal. $\mathrm{com} / \mathrm{pr} / 3879134$.

Dokuzparmak, E., Sirin, Y., Cakmak, U., Ertunga, S.N., 2017. Purification and characterization of a novel thermostable phytase from the thermophilic Geobacillus sp. TF16. Int. J. Food Properties 20 (5), 1104-1116.

Dombkowski, A.A., Sultana, K.Z., Craig, D.B., 2014. Protein disulfide engineering. FEBS Lett. 588 (2), 206-212. https://doi.org/10.1016/j.febslet.2013.11.024. Epub 2013 Nov 26.

Don Cannon, 2014. How ethanol production technology impacts DDGS value in animal nutrition. 18th Annual Distillers Grains Symposium. Danisco Animal Nutrition, Dallas, TX; DuPont.

Dorthe, K.R., 2010. Difference in Heat Stability of Phytase and Xylanase Products in Pig Feed. Trial Report 875 September 1, 2010. Pig Research Centre, Danish Agriculture and Food Council.

Drejer, E.B., Hakvag, S., Irla, M., Brautaset, T., 2018. Genetic tools and techniques for recombinant expression in thermophilic Bacillaceae. Microorganisms 10 (6(2)). https://doi.org/10.3390/microorganisms6020042. pii: E42.

Edens, F.W., Parkhurst, C.R., Ferket, P.R., Havenstein, G.B., Sefton, A.E., 2002. A demonstration of postpellet application of dry phytase to broiler diets. J. Appl. Poult. Res. 11 (1), 34-45.

Fasimoye, F.O., Olajuyigbe, F.M., Sanni, M.D., 2014. Purification and characterization of a thermostable extracellular phytase from Bacillus licheniformis PFBL-03. Prep. Biochem. Biotechnol. 44 (2), 193-205. https://doi.org/10.1080/10826068.2013. 812565.

Fei, B., Cao, Y., Xu, H., Li, X., Song, T., Fei, Z., Qiao, D., Cao, Y., 2013a. AppA C-terminal plays an important role in its thermostability in Escherichia coli. Curr. Microbiol. 66, 374-378.

Fei, B., Xu, H., Cao, Y., Ma, S., Guo, H., Song, T., Qiao, D., Cao, Y., 2013b. A multi-factors rational design strategy for enhancing the thermostability of Escherichia coli AppA phytase. J. Ind. Microbiol. Biotechnol. 40 (5), 457-464.

Fonseca-Maldonado, R., Maller, A., Bonneil, E., Thibault, P., Botelho-Machado, C., Ward, R.J., Polizeli Mde, L., 2014. Biochemical properties of glycosylation and characterization of a histidine acid phosphatase (phytase) expressed in Pichia pastoris. Protein Exp. Purif. 99, 43-49.

Frontela, C., Garcia-Alonso, F.J., Ros, G., Martinez, C., 2008. Phytic acid and inositol phosphates in raw flours and infant cereals: the effect of processing. J. Food Compos. Anal. 21, 343-350.

Fu, S., Sun, J., Qian, L., Li, Z., 2008. Bacillus phytases: present scenario and future perspectives. Appl. Biochem. Biotechnol. 151 (1), 1-8. https://doi.org/10.1007/s12010008-8158-7. Epub 2008 Feb 20.

Fu, D., Huang, H., Meng, K., Wang, Y., Luo, H., Yang, P., Yuan, T., Yao, B., 2009. Improvement of Yersinia frederiksenii phytase performance by a single amino acid substitution. Biotechnol. Bioeng. 103 (5), 857-864. https://doi.org/10.1002/bit. 22315.

Ghasemian, A., Ebrahimi, S., Jamei, R., Mostafavi, S., 2017. In Silico comparison of disulfide-bearing and disulfide-free phytases among microorganisms. J. Pharm. Nutr. Sci. 7, 24-34. https://doi.org/10.6000/1927-5951.2017.07.01.4.

Grand view research, 2017. Animal Feed Enzymes Market Analysis by Product (Phytases, Carbohydrases, proteases), by Formulation (Liquid, Dry), by Application (Poultry, Pigs, Ruminant, Pets, Aqua), by, and Segment Forecasts, 2018-2025. Report ID: GVR1-68038-759-9. https://www.grandviewresearch.com/industry-analysis/animalfeed-enzymes-industry.

Han, Y., Lei, X.G., 1999. Role of glycosylation in the functional expression of an Aspergillus niger phytase (phyA) in Pichia pastoris. Arch. Biochem. Biophys. 364 (1), 83-90.

He, Q., Reis, C.E.R., Wang, F., Hu, B., 2017. Phytate extraction from coproducts of the dry-grind corn ethanol process. RSC Adv. 7, 5466-5472.

Hibbert, E.G., Dalby, P.A., 2005. Directed evolution strategies for improved enzymatic performance. Microb. Cell Fact. 4, 29. https://doi.org/10.1186/1475-2859-4-29.

Illanes, A., 1999. Stability of biocatalysts. EJB Electron. J. Biotechnol. 2 (1) OI: 10.2225 vol2-issue1-fulltext-2.

International poultry production, 2014. Feed Enzyme Innovation - Past, Present and Potential. DANISCO Animal Nutrition - Enzymes Supplement. http:// animalnutrition.dupont.com/fileadmin/user_upload/live/animal_nutrition/ documents/open/Feed-enzyme-innovation-International-Poultry-ProductionSeptember 2014.pdf.

Isakova, E.P., Serdyuk, E.G., Gessler, N.N., Trubnikova, E.V., Biryukova, Y.K., Epova, E.Y., Deryabina, Y.I., Nikolaev, A.V., 2018. A new recombinant strain of Yarrowia lipolytica producing encapsulated phytase from Obesumbacterium proteus. Dokl. Biochem. Biophys. 481 (1), 201-204. https://doi.org/10.1134/S1607672918040063.

Jain, J., Kumar, A., Singh, D., Singh, B., 2018. Purification and kinetics of a proteaseresistant, neutral, and thermostable phytase from Bacillus subtilis subsp. subtilis JJBS250 ameliorating food nutrition. Prep. Biochem. Biotechnol. 17, 1-7. https:// doi.org/10.1080/10826068.2018.1487848.

Jongbloed, A.W., Kemme, P.A., 1990. Effect of pelleting mixed feeds on phytase activity and apparent absorbability of phosphorus and calcium in pigs. Anim. Feed Sci. Technol. 28, 233-242.

Jones, F.T., 2011. A review of practical Salmonella control measures in animal feed. J. Appl. Poult. Res. 20 (1), 102-113. https://doi.org/10.3382/japr.2010-00281.

Jones, F.T., Richardson, K.E., 2004. Salmonella in commercially manufactured feeds. Poult. Sci. 83, 384-391.

Jones, C.K., Tokach, M.D., Dritz, S.S., Ratliff, B.W., Horn, N.L., Goodband, R.D., DeRouchey, J.M., Sulabo, R.C., Nelssen, J.L., 2010. Efficacy of different commercial phytase enzymes and development of an available phosphorus release curve for Escherichia coli-derived phytases in nursery pigs. J. Anim. Sci. 88 (11), 3631-3644. https://doi.org/10.2527/jas.2010-2936. Epub 2010 Jul 30.

Kaur, P., Kunze, G., Satyanarayana, T., 2007. Yeast phytases: present scenario and future perspectives. Crit. Rev. Biotechnol. 27 (2), 93-109.

Keiji, F., Hideyuki, K., Haruhiko, M., Shodo, H., 2004. Effect of cellular inositol content on ethanol tolerance of Saccharomyces cerevisiae in sake brewing. J. Biosci. Bioeng. 98, $107-113$.

Kensch, O., Schulze, P.K., Leuthner, B., Shetty, J., Pepsin, M., Faurschou, S.D.M., 2016. Buttiauxella sp. Phytase Variants. EP2283124B1. Danisco US Inc.

Khullar, E., Shetty, J.K., Rausch, K.D., Tumbleson, M.E., Singh, V., 2011. Use of phytases in ethanol production from E-Mill corn processing. Cereal Chem. 88 (3), 223-227.

Kim, M.S., Lei, X.G., 2008. Enhancing thermostability of Escherichia coli phytase AppA2 by error-prone PCR. Appl. Microbiol. Biotechnol. 79 (1), 69-75.

Kim, M.S., Weaver, J.D., Lei, X.G., 2008. Assembly of mutations for improving thermostability of Escherichia coli AppA2 phytase. Appl. Microbiol. Biotechnol. 79, 751-758.

Kumar, K., Dixit, M., Khire, J., Pal, S., 2013. Atomistic details of effect of disulfide bond reduction on active site of Phytase B from Aspergillus niger: A MD Study. Bioinformation 9 (19), 963-967.

Lamid, M., Al-Arif, A., Asmarani, O., Warsito, S.H., 2018. Characterization of phytase enzymes as feed additive for poultry and feed. IOP Conf. Ser. Earth Environ. Sci. 137 (1).

Lewis, L.L., 2011. Evaluation of Pelleting Process Parameters on Feed Nutrients, Starch Gelatinization and Pig Growth Performance (MSc Thesis). Kansas State University.

Liu, K., 2014. Treating thin stillage and condensed distillers solubles with phytase for production of low-phytate coproducts. Cereal Chem. 91 (1), 72-78.

Loop, S.A., Lilly, K.G.S., Shires, L.K., Gehring, C.K., Beaman, K.R., Persia, M.E., Moritz, J.S., 2012. The phytase analytical activity of pelleted diets may not adequately describe efficacy in the bird. J. Appl. Poult. Res. 21 (3), 492-501. https://doi.org/10. 3382/japr.2011-00384.

Luangthongkam, P., Fang, L., Noomhorm, A., Lamsal, B., 2015. Addition of cellulolytic enzymes and phytase for improving ethanol fermentation performance and oil recovery in corn dry grind process. Ind. Crops Prod. 77, 803-808.

Makolomakwa, M., Puri, A.K., Permaul, K., Singh, S., 2017. Thermo-acid-stable phytasemediated enhancement of bioethanol production using Colocasia esculenta. Bioresour. Technol. 235, 396-404.

Menezes-Blackburn, D., Jorquera, M., Gianfreda, L., Rao, M., Greiner, R., Garrido, E., de la Luz Mora, M., 2011. Activity stabilization of Aspergillus niger and Escherichia coli phytases immobilized on allophanic synthetic compounds and montmorillonite 
nanoclays. Bioresour. Technol. 102 (20), 9360-9367. https://doi.org/10.1016/j. biortech.2011.07.054.

Menezes-Blackburn, D., Gabler, S., Greiner, R., 2015. Performance of seven commercial phytases in an in vitro simulation of poultry digestive tract. J. Agric. Food Chem. 63 (27), 6142-6149. https://doi.org/10.1021/acs.jafc.5b01996. Epub 2015 Jul 2.

Mikulski, D., Kłosowski, G., 2015. Phytic acid concentration in selected raw materials and the analysis of its hydrolysis rate with the use of microbial phytases during the mashing process. J. Inst. Brew. 121, 213-218.

Mikulski, D., Kłosowski, G., Rolbiecka, A., 2015. Influence of phytase and supportive enzymes applied during high gravity mash preparation on the improvement of technological indicators of the alcoholic fermentation process. Biomass Bioenergy 80, 191-202.

Monteiro, P.S., Guimarães, V.M., de Melo, R.R., de Rezende, S.T., 2015. Isolation of a thermostable acid phytase from Aspergillus niger UFV-1 with strong proteolysis resistance. Braz. J. Microbiol. 46 (1), 251-260.

Mullaney, E.J., Daly, C.B., Ullah, A.H., 2000. Advances in phytase research. Adv. Appl. Microbiol. 47, 157-199.

Mullaney, E.J., Locovare, H., Sethumadhavan, K., Boone, S., Lei, X.G., Ullah, A.H., 2010. Site-directed mutagenesis of disulfide bridges in Aspergillus niger NRRL 3135 phytase (PhyA), their expression in Pichia pastoris and catalytic characterization. Appl Microbiol. Biotechnol. 87 (4), 1367-1372.

Mullaney, E.J., Locovare, H., Sethumadhavan, K., Boone, S., Lei, X.G., Ullah, A.H., 2012. Elimination of a disulfide bridge in Aspergillus niger NRRL 3135 Phytase (PhyA) en hances heat tolerance and optimizes its temperature versus activity profile. Adv. Biol. Chem. 2, 372-378.

Naghshbandi, M.P., Moghimi, H., Latif, B., 2018. Covalent immobilization of phytase on the multi-walled carbon nanotubes via diimide-activated amidation: structural and stability study. Artif. Cells Nanomed. Biotechnol. 8, 1-10. https://doi.org/10.1080/ 21691401.2018.1435550.

Niu, C., Yang, P., Luo, H., Huang, H., Wang, Y., Yao, B., 2017. Engineering of Yersinia phytases to improve pepsin and trypsin resistance and thermostability and application potential in the food and feed industry. J. Agric. Food Chem. 65, 7337-7344.

Noorbatcha, I.A., Sultan, A.M., Salleh, H.M., Amid, A., 2013. Understanding thermostability factors of Aspergillus niger PhyA phytase: a molecular dynamics study. Protein J. 32 (4).

Noureddini, H., Dang, J., 2009. Degradation of phytates in distillers' grains and corn gluten feed by Aspergillus niger phytase. Appl. Biochem. Biotechnol. 159, 11-23.

Oh, B.C., Choi, W.C., Park, S., Kim, Y.O., Oh, T.K., 2004. Biochemical properties and substrate specificities of alkaline and histidine acid phytases. Appl. Microbiol. Biotechnol. 63 (4), 362-372 Epub 2003 Oct 28.

Pandee, P., Summpunn, P., Wiyakrutta, S., Isarangkul, D., Meevootisom, V., 2011. A thermostable phytase from Neosartorya spinosa BCC 41923 and its expression in Pichia pastoris. J. Microbiol. 49 (2), 257-264. https://doi.org/10.1007/s12275-0110369-x. Epub 2011 May 3.

Patridge, G., 2007. New-generation phytase with high thermostability. PIG Progress 23 (4).

Priyodip, P., Prakash, P.Y., Balaji, S., 2017. Phytases of probiotic bacteria: characteristics and beneficial aspects. Indian J. Microbiol. 57 (2), 148-154.

Raboy, V., Young, K.A., Dorsch, J.A., Cook, A., 2001. Genetics and breeding of seed phosphorus and phytic acid. J. Plant Physiol. 158, 489-497.

Rathnayake, U.A., Senapathi, T., Sandaruwan, C., Gunawardene, S., Karunaratne, V., Kottegoda, N., 2018. Rice bran nanofiber composites for stabilization of phytase. Chem. Cent. J. 12 (1), 28.

Ravindran, V., 2013a. Poultry feed availability and nutrition in developing countries main ingredients used in poultry feed formulations. In: Poultry Development Review. FAO, Rome, Italy, pp. 1-3.

Ravindran, V., 2013b. Feed enzymes: the science, practice, and metabolic realities. J. Appl. Poult. Res. 22 (3), 628.

Rebello, S., Jose, L., Sindhu, R., Aneesh, E.M., 2017. Molecular advancements in the development of thermostable phytases. Appl. Microbiol. Biotechnol. 101 (7), 2677-2689. https://doi.org/10.1007/s00253-017-8195-7.

Rigoldi, F., Donini, S., Redaelli, A., Parisini, E., Gautieri, A., 2018. Review: engineering of thermostable enzymes for industrial applications. APL Bioeng. 2 (1), 011501. https:// doi.org/10.1063/1.4997367.

Rocky-Salimi, K., Hashemi, M., Safari, M., Mousivand, M., 2016. A novel phytase characterized by thermostability and high $\mathrm{pH}$ tolerance from rice phyllosphere isolated Bacillus subtilis B.S.46. J. Adv. Res. 7 (3), 381-390. https://doi.org/10.1016/j.jare. 2016.02.003.

Rodriguez, E., Wood, Z.A., Karplus, P.A., Lei, X.G., 2000. Site-directed mutagenesis improves catalytic efficiency and thermostability of Escherichia coli pH 2.5 acid phosphatase/phytase expressed in Pichia pastoris. Arch. Biochem. Biophys. 382 (1) 105-112.

Rodríguez-Fernández, D.E., Parada, J.L., Medeiros, A.B.P., de Carvalho, J.C., Lacerda, L.G., Rodríguez-León, J.A., Soccol, C.R., 2013. Concentration by ultrafiltration and stabilization of phytase produced by solid-state fermentation. Process Biochem. 48 (2), 374-379.

Sabir, F., Tayyab, M., Muneer, B., Hashmi, A.S., Awan, A.R.A., Rashid, N., Firyal, S., 2017. Characterization of recombinant thermostable phytase from Thermotoga naphthophila: a step for the fulfilment of domestic requirement of phytase in Pakistan. Pakistan J. Zool. 49 (6). https://doi.org/10.17582/journal.pjz/2017.49.6.1945.1951.

Sarmiento, F., Peralta, R., Blamey, J.M., 2015. Cold and hot extremozymes: industrial relevance and current trends. Front. Bioeng. Biotechnol. 3, 148. https://doi.org/10. 3389/fbioe.2015.00148.

Selle, P.H., Ravindran, V., 2007. Microbial phytase in poultry nutrition. Anim. Feed Sci. Technol. 135, 1-41.

Shankar, S., Soni, S.K., Daima, H.K., Selvakannan, P.R., Khire, J.M., Bhargava, S.K.,
Bansal, V., 2015. Charge-switchable gold nanoparticles for enhanced enzymatic thermostability. PCCP 17, 21517-21524.

Shanmugam, G., 2018. Characteristics of phytase enzyme and its role in animal nutrition. Int. J. Curr. Microbiol. Appl. Sci. 7 (3), 1006-1013.

Shetty, J.K., Paulson, B., Pepsin, M., Chotani, G., Dean, B., Hruby, M., 2008. Phytase in fuel ethanol production offers economical and environmental benefits. Int. Sugar J. 110 (1311), 160-174.

Shivange, A.V., Dennig, A., Schwaneberg, U., 2014. Multi-site saturation by OmniChange yields a pH-and thermally improved phytase. J. Biotechnol. 170, 68-72.

Shivange, A.V., Schwaneberg, U., 2017. Recent Advances in Directed Phytase Evolution and rational Phytase Engineering. Directed Enzyme Evolution: Advances and Applications. Springer, New York, pp. 145-172.

Shivange, A.V., Roccatano, D., Schwaneberg, U., 2016. Iterative key-residues interrogation of a phytase with thermostability increasing substitutions identified in directed evolution. Appl. Microbiol. Biotechnol. 100 (1), 227-242.

Solá, R.J., Griebenow, K., 2009. Effects of glycosylation on the stability of protein pharmaceuticals. J. Pharm. Sci. 98 (4), 1223-1245.

Song, G.Y., Wang, X.Y., Wang, M., 2005. Influence of disulfide bonds on the conformational changes and activities of refolded phytase. Protein Pept. Lett. 12 (6), 533-535.

Tahir, M., Shim, M.Y., Ward, N.E., Smith, C., Foster, E., Guney, A.C., Pesti, G.M., 2012 Phytate and other nutrient components of feed ingredients for poultry. Poult. Sci. 91, 928-935.

Tan, H., Miao, R., Liu, T., Cao, X., Wu, X., Xie, L., Huang, Z., Peng, W., Gan, B., 2016a. Enhancing the thermal resistance of a novel acidobacteria-derived phytase by engineering of disulfide bridges. J. Microbiol. Biotechnol. 26 (10), 1717-1722.

Tan, H., Wu, X., Xie, L., Huang, Z., Peng, W., Gan, B., 2016b. Identification and characterization of a mesophilic phytase highly resilient to high-temperatures from a fungus-garden associated metagenome. Appl. Microbiol. Biotechnol. 100 (5), 2225-2241. https://doi.org/10.1007/s00253-015-7097-9.

Tan, X., Solbak Jr., A.I., 2018. BASF Enzymes LLC, Phytase. US9879238B2.

Turner, P., Mamo, G., Karlsson, E.N., 2007. Potential and utilization of thermophiles and thermostable enzymes in biorefining. Microbial Cell Factories 6, 9. https://doi.org/ 10.1186/1475-2859-6-9. Published 2007 Mar 15.

Ullah, A.H., Mullaney, E.J., 1996. Disulfide bonds are necessary for structure and activity in Aspergillus ficuum phytase. Biochem. Biophys. Res. Commun. 227 (2), 311-317.

Ushasree, M.V., Krishna, Shyam, Vidya, J., Pandey, A., 2017. Microbial phytase: impact of advances in genetic engineering in revolutionizing its properties and applications. Bioresour. Technol. 245 (Pt B), 1790-1799.

Ushasree, M.V., Vidya, J., Pandey, A., 2014. Extracellular expression of a thermostablephytase (phyA) in Kluyveromyceslactis. Process Biochem. 49 (9), 1440-1447.

Ushasree, M.V., Vidya, J., Pandey, A., 2016. Other enzymes phytases. In: Pandey, A., Negi, Soccol, C. (Eds.), Current Developments in Biotechnology and Bioengineering: Production, Isolation and Purification of Industrial Products. Elsevier, pp. 309-333.

Vandenberg, G.W., Scott, S.L., Sarker, P.K., Dallaire, V.J., de la Noüe, V.J., 2011. Encapsulation of microbial phytase: effects on phosphorus bioavailability in rainbow trout (Oncorhynchus mykiss). Anim. Feed Sci. Technol. 169 (3-4), 230-243.

Veit, C., Felby, C., Peckous, L.W., Olsen, H.S., 2001. Fermentation With a Phytase, WO2001062947A1. Novozymes A/S.

Vieille, C., Zeikus, J.G., 1996. Thermozymes: identifying molecular determinants of protein structural and functional stability. Trends Biotechnol. 14 (6), 183-190.

Vijayaraghavan, P., Primiya, R.R., Prakash, V.S.G., 2013. Thermostable alkaline phytase from Alcaligenes sp. in improving bioavailability of phosphorus in animal feed. In Vitro Anal. 6. https://doi.org/10.5402/2013/394305.

Vohra, A., Satyanarayana, T., 2003. Phytases: microbial sources, production, purification, and potential biotechnological applications. Crit. Rev. Biotechnol. 23 (1), 29-60.

Wang, X., Du, J., Zhang, Z.Y., Fu, Y.J., Wang, W.M., Liang, A.H., 2018. A rational design to enhance the resistance of Escherichia coli phytase appA to trypsin. Appl. Microbiol. Biotechnol. https://doi.org/10.1007/s00253-018-9327-4.

Wang, X., Yao, M., Yang, B., Fu, Y., Hu, F., Liang, A., 2015. Enzymology and thermal stability of phytase appA mutants. RSC Adv. 5, 43863-43872.

Wang, X.Y., Meng, F.G., Zhou, H.M., 2004. The role of disulfide bonds in the conformational stability and catalytic activity of phytase. Biochem. Cell Biol. 82 (2), 329-334.

Wu, T.H., Chen, C.C., Cheng, Y.S., Ko, T.P., Lin, C.Y., Lai, H.L., Huang, T.Y., Liu, J.R., Guo, R.T., 2014. Improving specific activity and thermostability of Escherichia coli phytase by structure-based rational design. J. Biotechnol. 175, 1-6.

Wu, D., Wu, S.B., Choct, M., Swick, R.A., 2015. Comparison of 3 phytases on energy utilization of a nutritionally marginal wheat-soybean meal broiler diet. Poult. Sci. 94 (11), 2670-2676. https://doi.org/10.3382/ps/pev222.

Wyss, M., Brugger, R., Kronenberger, A., Rémy, R., Fimbel, R., Oesterhelt, G., Lehmann, M., van Loon, A.P., 1999. Biochemical characterization of fungal phytases (myo-inositol hexakisphosphate phosphohydrolases): catalytic properties. Appl. Environ. Microbiol. 65 (2), 367-373.

Yao, M.Z., Wang, X., Wang, W., Fu, Y.J., Liang, A.H., 2013. Improving the thermostability of Escherichia coli phytase, appA, by enhancement of glycosylation. Biotechnol. Lett. $35,1669-1676$.

Zhang, W., Mullaney, E.J., Lei, X.G., 2007. Adopting selected hydrogen bonding and ionic interactions from Aspergillus fumigatus phytase structure improves the thermostability of Aspergillus niger PhyA phytase. Appl. Environ. Microbiol. 73 (9), 3069-3076.

Zhang, J., Liu, Y., Gao, S., Zhu, L., Li, W., Tian, X., Liu, Y., 2016. Site-directed mutagenesis and thermal stability analysis of phytase from Escherichia coli. Biosci. Biotechnol. Res. Commun. 9, 357-365.

Zhao, Q., Liu, H., Zhang, Y., Zhang, Y., 2010. Engineering of protease resistant phytase from Penicillium sp.: high thermal stability, low optimal temperature and $\mathrm{pH}$. J. Biosci. Bioeng. 110, 638-645. 